\title{
Implementasi Akad Murabahah dan Ijarah Muntahiyah Bit Tamlik Pada Produk KPR BRI Syariah KC Malang Kawi
}

\author{
Winda Ika Pratiwi \& Moch Novi Rifa'i \\ Program Studi Ekonomi Syariah, Fakultas Agama Islam, \\ Universitas Muhammadiyah Malang \\ E-mail: windaikapratiwi@gmail.com
}

\begin{abstract}
This study aims to explain how the mechanism of mortgage product (KPS) at BRI Syariah. In each bank, there is a different use of the contract on the mortgage product, although the contract used remains based on the contract in accordance with Islamic Sharia. By using interview and survey methods to find out the mechanism of mortgage product at bank BRI Syariah KC Malang Kawi. The result of shows that mortgage product (KPR) in BRI Syariah consists of two kinds: namely mortgage product (KPR) Faedah and ijarah muntahiyah bit tamlik (IMBT); where KPR Faedah using murabahah contract and IMBT using ijarah muntahiyah bit tamlik (IMBT). In the essence, both of two products issued by BRI Syariah are the same, there are only different in working mechanism. In KPR Faedah, the principal installment will be greater each installment period until the end of repayment. While the principal installment of KPR IMBT is fixed from the beginning of the installment period until the end of repayment. The term used also differs between the products KPR Faedah and KPR IMBT; where in KPR Faedah used the term 'installment margin' for the benefit of the bank, and on IMBT mortgage product used the term 'installment ujrah'.
\end{abstract}

Keywords: mortgage products, Murabahah, Ijarah Muntahiyah Bit Tamlik (IMBT)

\section{Pendahuluan}

Produk KPR merupakan produk yang dikeluarkan oleh kalangan perbankan dalam rangka membantu masyarakat memenuhi kebutuhan perumahan mereka. Keikutsertaan kalangan perbankan dalam membantu pengadaan perumahan bagi masyarakat sangat penting karena merupakan bagian dari program pemerintah untuk membantu pengadaan bagi masyarakat. Pentingnya masalah perumahan tersebut membuat pemerintah bersama DPR telah mengeluarkan UU No 4 tahun 
1992 yang menegaskan dalam Bab 1 pasal 1 :"rumah adalah bangunan yang berfungsi sebagai tempat atau hunian dan sarana pembinaan keluarga". Dalam dunia perbankan, produk ini biasa dinamakan dengan kredit pemilikan rumah atau biasa dikenal dengan nama KPR. Produk KPR yang biasa dijalankan oleh perbankan konvensional tersebut dapat dipastikan tidak akan lepas dari bunga yang merupakan ciri utama dari bank konvensinal. Pada KPR konvensional biasa terlibat berbagai unit-unit lain seperti pihak perseroan terbatas yang akan menyediakan lokasi yang dipergunakan dalam kegiatan pembangunan rumah.

Produk KPR yang ada pada perbankan syariah pada dasarnya berbeda dengan KPR yang ada di perbankan konvensional. Perbedaan ini dapat terjadi karena terdapat perbedaan prinsip antara perbankan syariah dengan perbankan konvensional. Perbankan syariah menggunakan konsep berbasis bagi hasil dan perdagangan. Berbeda dengan perbankan konvensional yang menggunakan sistem berbasis bunga. Pada produk yang biasa dikenal dengan KPR syariah ini terdapat beberapa karakteristik yang berbeda, diantaranya adalah tidak adanya pemberlakuan sistem kredit yang ada pada perbankan konvensional. Pada perbankan syariah dikenal sistem murabahah yang berbasis margin, musyarakah mutanaqishah yang memiliki ciri khas partisipasi kepemilikan. ${ }^{1}$ Selain itu ada pula beberapa perbankan syariah yang menggunakan akad ijarah muntahiyah bit tamlik pada produk KPR yang ditawarkan. Bank syariah merupakan dikatagorikan sebagai lembaga keuangan bank. Bank syariah dapat berbentuk bank umum syariah (BUS) maupun bank perkreditan rakyat syariah (BPRS) menurut Undangundang no 21 tahun 2008 tentang perbankan syariah Indonesia, dijelaskan bahwa bank syariah yang kegiatan usahanya berdasarkan prinsip syariah. Bank Umum Syariah (BUS) adalah bank yang kegiatannya memberikan jasa dalam lalulintas pembayaran. Adapun Bank Perkreditan Rakyat Syariah (BPRS) adalah bank syariah yang kegiatan usahanya tidak memberikan jasa dalam lalu lintas pembayaran. ${ }^{2}$ Bank berdasarkan prinsip syariah, atau bank Islam, seperti halnya bank konvensional, juga berfungsi sebagai suatu lembaga intermediasi (intermediary institution), yaitu mengerahkan dana dari masyarakat yang membutuhkannya dalam bentuk fasilitas pembiayaan. Perbankan syariah menyebut leasing (sewa-beli) sebagai ijarah. Secara harfiah ijarah berarti memberikan sesuatu dengan sewa, dan secara teknis ia menyangkut penggunaan property milik orang lain berdasarkan ongkos sewa yang diminta. Konsekuensinya, suatu ijarah didasarkan pada perjanjian antara orang yang menyewakan dan penyewa atas penggunaan asset tertentu. Orang yang menyewakan tetap sebagai pemilik asset dan penyewa menguasai serta menggunakan asset tersebut dengan membayar uang sewa tertentu untuk suatu

1 Mohamad Haekal. Analisis Tingkat Pemahaman KPR Syariah pada Bank Syariah di Indonesia: Studi Pendahuluan. (Binus Business Review 5.2, 2014), 519-526.

2 Kautsar Riza Salman. Akuntansi Perbankan Syariah Berbasis PSAK Syariah. (Jakarta: Akademia Permata, 2012), 2. 
periode waktu tertentu. ${ }^{3}$ Masalah penentuan keuntungan pada setiap produk yang dikeluarkan menjadi salah satu hal yang penting berkaitan dengan akad yang digunakan. Hal ini dikarenakan bank syariah juga memegang peranan sebagai lembaga yang berfungsi sebagai lembaga intermediary, atau lembaga perantara dari pihak yang mengalami surplus dana kepada pihak yang mengalami defisit dana. Adanya peranan seperti itu, tentunya diharapkan akan terdapat keuntungan produk KPR syariah yang merupakan produk yang dikeluarkan bagi nasabah yang memerlukan pembiayaan dari bank syariah untuk mendapatkan rumah. Keuntungan itu adalah margin keuntungan yang nilainya tetap selama masa perjanjian tersebut. Margin keuntungan yang sifatnya tetap tersebut, maka besarnya cicilan yang harus dibayarkan oleh pihak nasabah kepada bank syariah tidak akan berubah dan juga tidak akan memberatkan nasabah. Hal inilah yang membedakan antara bank syariah dan konvensional. Berdasarkan konsep KPR syariah, maka penentuan harga dan juga keuntungan yang ada didalam KPR syariah harus memenuhi beberapa hal yang penting yaitu, (a) kauntungan yang diminta oleh bank syariah dan juga harus diketahui secara jelas oleh nasabah; (b) harga jual bank yang merupakan harga beli bank ditambah dengan keuntungan yang diambil oleh bank; (c) harga jual yang tidak boleh berubah selama perjanjian; (d) sistem pembayaran yang telah disepakati bersama. ${ }^{4}$

\section{Murabahah: Definisi, Landasan Hukum dan Mekanisme Kerja}

Secara bahasa, murabahah atau jual beli adalah pertukaran sesuatu dengan sesuatu yang lain. Istilah lain darikaya jual beli (al-bay') adalah 'asy-syira', al'mubadah', dan 'at-tijarah'. Berkenaan dengan kata 'at-tijarah', dalam al-Qur'an QS. Fathir[35]: 29 yang artinya, "Mereka mengharapkan tijarah (perdagangan) yang tidak akan rugi”. Adapun jual beli secara istilah adalah sebagai berikut: (1) menurut ulama' Hanafiyah, jual beli adalah pertukaran harta dengan harta berdasarkan cara khusus yang dibolehkan. (2) menurut Imam Nawawi dalam almajmu', jual beli adalah pertukaran harta dengan harta untuk kepemilikan. Menurut Ibnu Qudamah dalam kitab al-Mugni jual beli adalah pertukaran harta dengan harta untuk saling menjadikan milik. ${ }^{5}$ Jual beli merupakan transaksi yang dilakukan oleh pihak penjual dan pembeli atas suatu barang dan jasa yang menjadi objek transaksi jual beli. Akad jual beli dapat diaplikasikan dalam pembiayaan yang diberikan oleh bank syariah. Pembiayaan yang menggunakan akad jual beli dikembangkan dalam tiga jenis produk pembiayaan, antara lain: pembiayaan murabahah, istishna' dan salam. Murabahah adalah akad jual beli atas barang tertentu, dimana penjual menyebutkan harga pembelian barang kepada pembeli

\footnotetext{
${ }^{3}$ Latifa M. Algaud, \& Mervy K Lewis. Perbankan Syariah Prinsip, Dan Prospek. (Jakarta: PT. Serambi Ilmu Semesta, 2003), 87.

${ }^{4}$ Haris, H, Pembiayaan Kepemilikan Rumah, (sebuah inovasi pembiayaan perbankan syariah), (La Riba: Jurnal Ekonomi Islam, 1(1), 2007), 113-125.

${ }^{5}$ Rachmat Syafi'e, Fiqih Muamalah, (Bandung; CV Pustaka Setia, 2001), 73.
} 
kemudian menjual kepada pihak pembeli dengan mensyaratkan keuntungan yang diharapkan sesuai jumlah tertentu. Pada akad murabahah, penjual menjual barangnya dengan meminta kelebihan atas harga beli dengan harga jual. Perbedaan antara harga beli dengan harga jual barang disebut dengan margin keuntungan.

Murabahah adalah jual beli barang pada harga asal dengan tambahan keuntungan yang disepakati. Pada akad ini, penjual harus memberitahu harga pokok produk yang ia beli dan menentukan suatu tingkat keuntungan sebagai tambahan. Murabahah juga dapat dilakukan untuk pembelian secara pesanan dan biasa disebut sebagai murabahah kepada pemesan pembelian. Imam Syafi'i menamai transaksi sejenis ini dengan istilah 'al-amr bi asy-syira'; dimana calon pembeli atau pemesan beli dapat memesan kepada seseorang (sebut saja sebagai pembeli) untuk membelikan suatu barang tertentu yang diinginkannya. Kedua pihak membuat kesepakatan mengenai barang tersebut serta memungkinkan harga asal pembelian yang masih sanggup ditanggung pemesan. Setelah itu, kedua pihak juga harus menyepakati beberapa keuntungan atau tambahan yang harus dibayar pemesan. Jual beli antar kedua belah pihak dilakukan setelah barang tersebut berada ditangan pemesan. ${ }^{6}$ Pembayaran atas transaksi ini dapat dilakukan dengan cara membayar sekaligus pada saat jatuh tempo atau melakukan pembayaran angsuran selama jangka waktu yang disepakati. ${ }^{7}$

Adapun landasan hukum dari jual beli atau murabahah adalah sebagai berikut:

a) Landasan al-Qur'an,

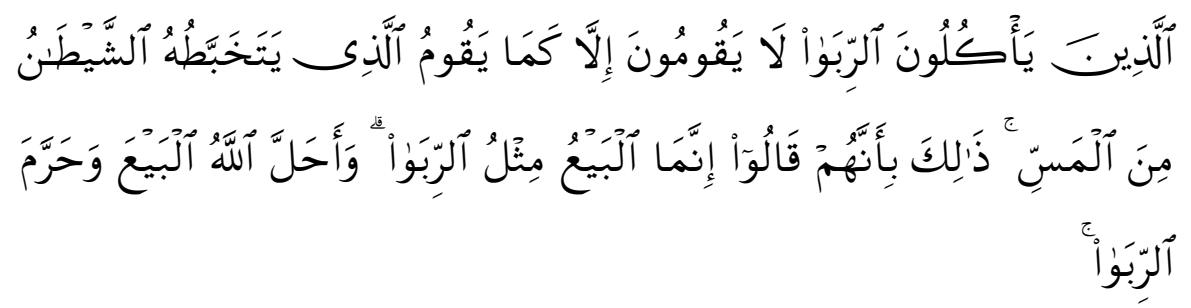

Artinya: "orang-orang yang Makan (mengambil) riba tidak dapat berdiri melainkan seperti berdirinya orang yang kemasukan syaitan lantaran (tekanan) penyakit gila. Keadaan mereka yang demikian itu, adalah disebabkan mereka berkata (berpendapat), Sesungguhnya jual beli itu sama dengan riba, Padahal Allah telah menghalalkan jual beli dan mengharamkan riba...”. (QS. AlBaqarah[2]: 275).

\footnotetext{
${ }^{6}$ Akhmad Mujahidin, Hukum Perbankan Syariah, (Jakarta; PT RajaGrafindo Persada, 2016), 54.

${ }^{7}$ Ismail, Perbankan Syariah, (Jakarta: Kencana Prenadamedia Group, 2011), 138.
} 


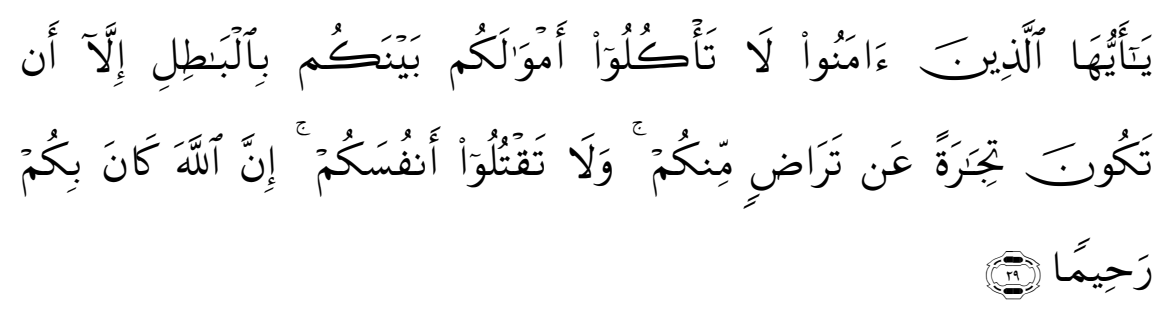

Artinya: "Hai orang-orang yang beriman, janganlah kamu saling memakan harta sesamamu dengan jalan yang batil, kecuali dengan jalan perniagaan yang Berlaku dengan suka sama-suka di antara kamu. dan janganlah kamu membunuh dirimu; Sesungguhnya Allah adalah Maha Penyayang kepadamu”. (QS. An-Nisa'[4]: 29)

b) Landasan Hadist,

$$
\text { أفضل الكسب عمل الرجل بيده وكل بيع مبرور }
$$

"Kerja yang paling utama adalah usaha seseorang dengan tangannya sendiri dan setiap jual-beli yang mabrur"

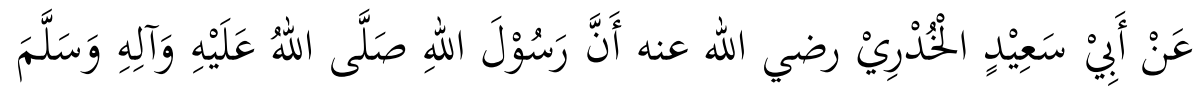

$$
\begin{aligned}
& \text { إِّمَا الْبَيْعُ عَنْ تَرَاضِ، (رواه البيهقي وابن ماجهه وصححه ابن حبان) :قَالَ }
\end{aligned}
$$

Dari Abu Sa'id Al-Khudri bahwa Rasulullah SAW bersabda, "Sesungguhnya jual beli itu harus dilakukan suka sama suka." (HR. alBaihaqi dan Ibnu Majah, dan dinilai shahih oleh Ibnu Hibban).

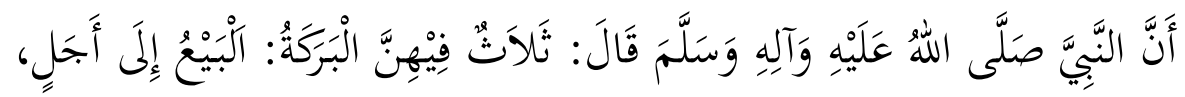

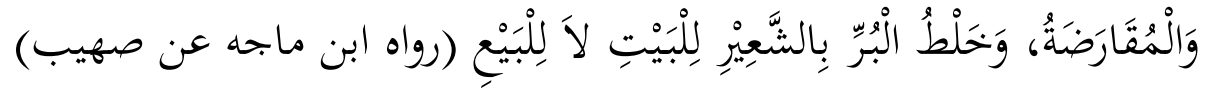

"Rasulullah Saw bersabda, "Terdapat tiga hal yang mengandung berkah: jual beli tidak secara tunai, muqaradhah (mudharabah), dan mencampur gandum dengan jewawut untuk keperluan rumah tangga, bukan untuk dijual. " (HR. Ibnu Majah). ${ }^{8}$

${ }^{8}$ M Ali Hasan, Berbagai Macam Transaksi Dalam Islam, (Jakarta: 2004, PT RajaGrafindo Persada), 116. 
Berdasarkan landasan di atas, ulama juga telah sepakat (ijma') bahwa jual beli diperbolehkan dengan alasan bahwa manusia tidak akan mempu mencukupi kebutuhan dirinya tanpa bantuan orang lain. Namun demikian, bantuan atau barang milik orang lain yang dibutuhkannya itu, harus diganti dengan barang lain yang sesuai. ${ }^{9}$

Adapun mekanisme kerja akad murabahah di perbankan syariah adalah sebagai berikut: ${ }^{10}$

\section{Gambar 2.1 Skema pembiayaan murabahah}

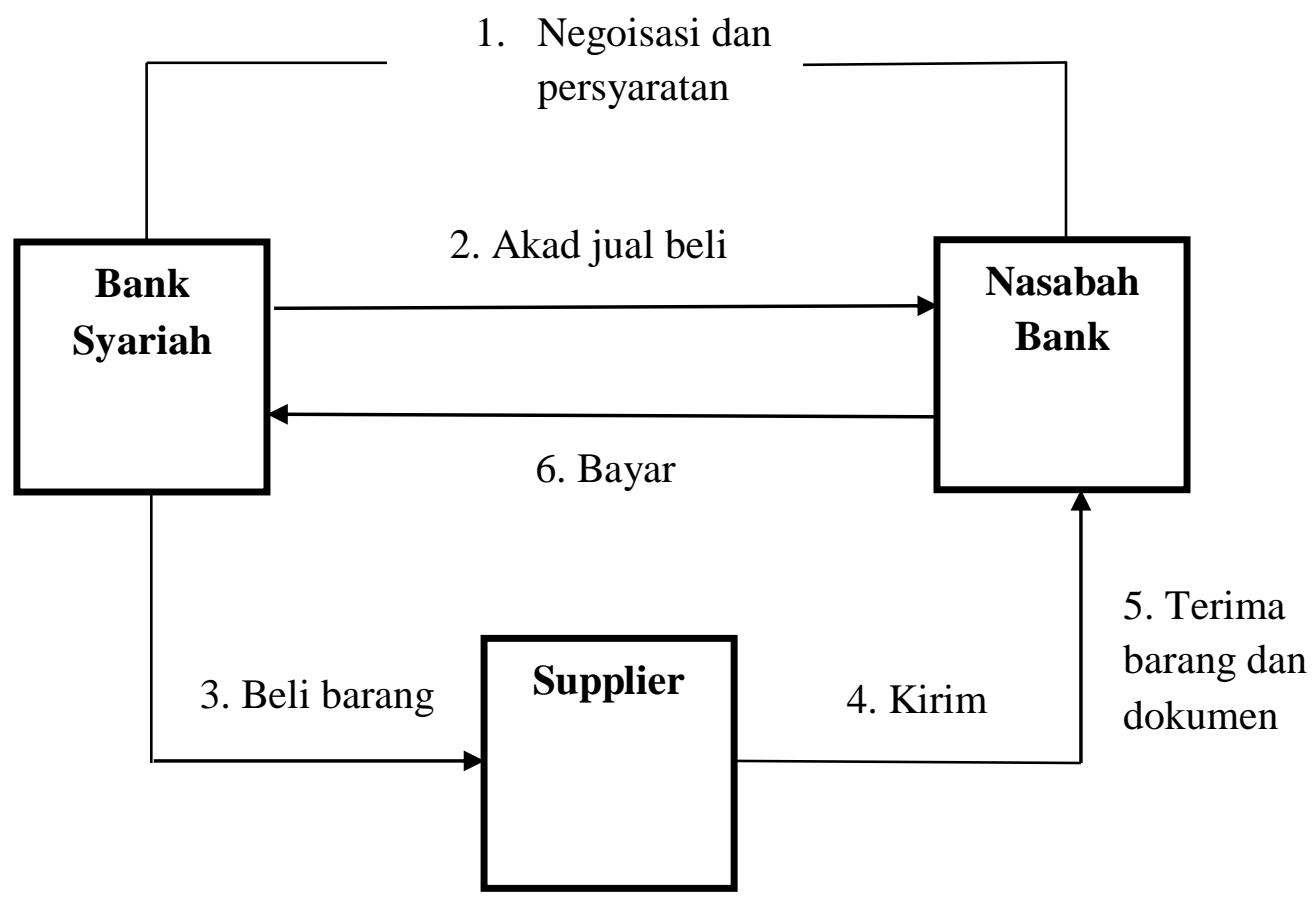

Keterangan:

a) Bank syariah dan nasabah melakukan negosiasi tentang rencana transaksi jual beli yang akan dilaksanakan. Poin negosiasi meliputi jenis barang yang akan dibeli, kualitas barang dan harga jual.

b) Bank syariah melakukan akad jual beli dengan nasabah, dimana bank syariah sebagai penjual dan nasabah sebagai pembeli. Dalam akad jual beli ini, ditetapkan barang yang menjadi objek jual beli yang telah dipilih oleh nasabah dan harga jual barang.

\footnotetext{
${ }^{9}$ Rachmat Syafi'e, Fiqih Muamalah ..., 73.

${ }^{10}$ Muhammad, Manajemen Bank Syariah... , 91. Lihat juga: Ismail, Perbankan Syariah..., 140.
} 
c) Atas dasar akad yang dilaksanakan antara bank syariah dan nasabah, maka bank syariah membeli barang dari supplier. Pembelian yang dilakukan oleh bank syariah ini sesuai dengan keinginan nasabah yang telah tertuang dalam akad.

d) Supplier mengirimkan barang kepada nasabah atas perintah bank syariah.

e) Nasabah menerima barang dari supplier dan menerima dokumen, maka nasabah melakukan pembayaran. Pembayaran yang lazim dilakukan oleh nasabah ialah dengan cara angsuran.

\section{Ijarah Muntahiyah Bit Tamlik: Definisi, Landasan Hukum dan Mekanisme Kerja K}

Ijarah muntahiyah bit tamlik adalah transaksi sewa menyewa antara pemilik objek sewa dan penyewa untuk mendapatkan imbalan atas objek sewa yang disewakannyadengan opsi perpindahan hak milik objek sewa. Dalam hal pembiayaan atas dasar ijarah muntahiyah bit tamlik, selain bank sebagai penyedia dana dalam kegiatan transaksi ijarah dengan nasabah, juga bertindak sebagai pemberi janji (wa'ad) antara lain untuk memberikan opsi pengalihan hak penguasaan objek sewa kepada nasabah sesuai kesepakatan. ${ }^{11}$ Dalam akad ini, pembiayaan yang diberikan oleh bank syariah berbentuk gabungan antara sewa dan jual beli. Pada periode pembiayaan, nasabah masih merupakan pihak penyewa, dan pada saat pembiayaan jatuh tempo, maka nasabah memiliki opsi untuk membeli aset yang disewa. Pada syariah Islam, ijarah dikenal dengan dua jenis yaitu ijarah dan ijarah muntahiyah bit tamlik. Ijarah muntahiyah bit tamlik disebut juga dengan 'ijarah wal iqtina', yang merupakan perjanjian sewa antara pihak pemilik aset tetap (lessor) dan penyewa (lessee), atas barang yang disewakan, penyewa mendapat hak opsi untuk membeli objek sewa pada saat masa sewa berakhir. Ijarah muntahiyah bit tamlik pada perbankan syariah dikenal dengan istilah 'financial lease'; yaitu gabungan antara transaksi sewa dan jual beli, karena pada akhir masa sewa, penyewa diberi hak opsi untuk membeli objek sewa. Pada akhir masa sewa, objek sewa akan berubah dari milik lessor menjadi lessee. $^{12}$

Adapun landasan hukum dari akad ini adalah meliputi ijma' para sahabat bahwa ijarah diperbolehkan sebab bermanfaat bagi manusia. ${ }^{13}$ Meskipun sebagian sahabat tidak menyepakatinya, dengan dalih bahwa ijarah adalah jual beli kemanfaatan, yang tidak dapat dipegang (tidak ada); dan sesuatu yang tidak ada, tidak dapat dikatagorikan sebagai jual beli. Adapun landasan al-Qur'an dan sunnah terkait akad ini adalah sebagai berikut,

\footnotetext{
${ }^{11}$ Muhamad, Manajemen Dana Bank, (Jakarta; PT RajaGrafindo Persada, 2014), 53.

12 Ismail, Perbankan Syariah..., 161.

${ }^{13}$ Rachmat Syafi'e, Fiqih Muamalah ..., 73.
} 


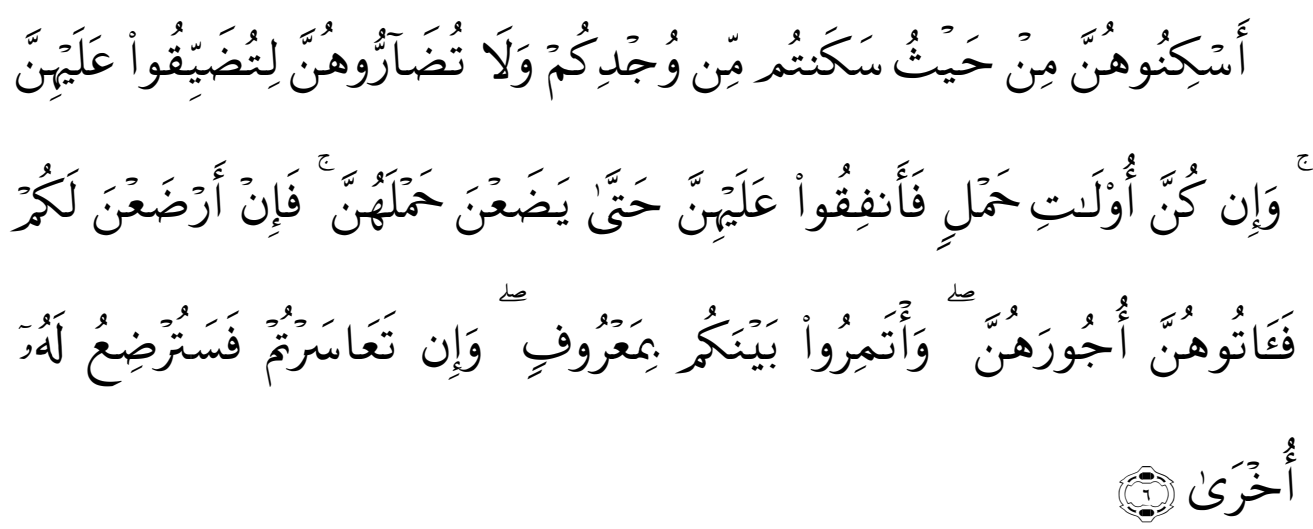

Artinya: "Tempatkanlah mereka (para isteri) di mana kamu bertempat tinggal menurut kemampuanmu dan janganlah kamu menyusahkan mereka untuk menyempitkan (hati) mereka. dan jika mereka (isteri-isteri yang sudah ditalaq) itu sedang hamil, Maka berikanlah kepada mereka nafkahnya hingga mereka bersalin, kemudian jika mereka menyusukan (anak-anak)mu untukmu Maka berikanlah kepada mereka upahnya, dan musyawarahkanlah di antara kamu (segala sesuatu) dengan baik; dan jika kamu menemui kesulitan Maka perempuan lain boleh menyusukan (anak itu) untuknya”. (QS. At-Thalaq[65]: 6)

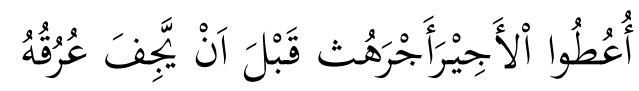

“Berikanlah upah pekerja sebelum keringatnya kering” (HR. Ibnu Majah)

Transaksi ijarah dilandasi adanya pemindahan manfaat. Pada dasarnya prinsip ijarah sama dengan prinsip jual beli, namun perbedaannya terletak pada objek transaksinya; apabila dalam jual beli obyek transaksinya adalah barang, maka pada ijarah obyek transaksinya berupa jasa. Pada akhir masa sewa, bank dapat saja menjual barang yang disewakan kepada nasabah atau yang dalam perbankan syariah dikenal ijarah muntahiyah bit tamlik (IMBT) atau sewa yang diikuti dengan berpindahnya kepemilikan. Harga sewa dan harga jual disepakati pada awal perjanjian. Adapun skema ijarah muntahiyah bit tamlik dapat digambarkan sebagai berikut: ${ }^{14}$

\footnotetext{
${ }^{14}$ Ismail, Perbankan Syariah..., 164.
} 


\section{Gambar 2.1 Mekanime Kerja Akad IMBT}

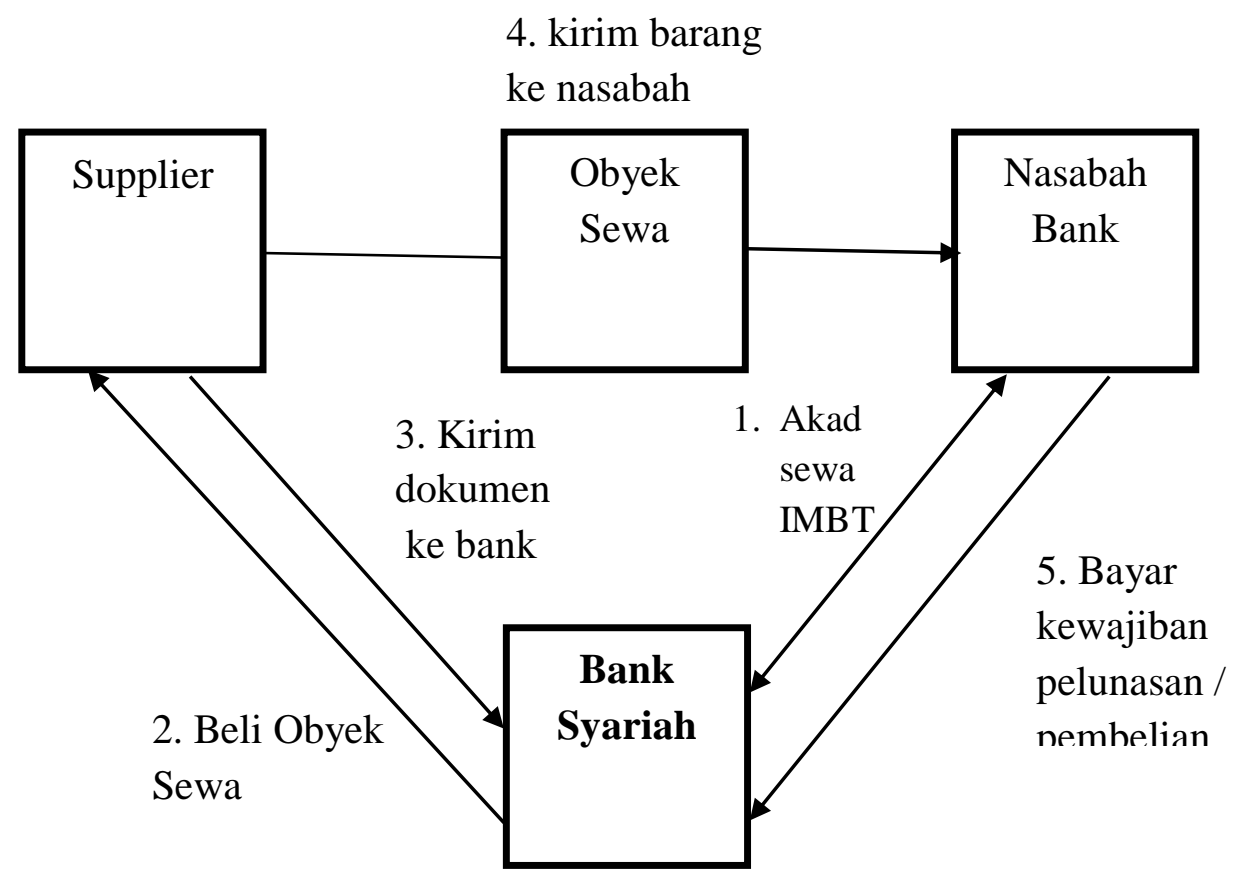

Keterangan:

a) Bank syariah dan nasabah melakukan perjanjian dengan akad ijarah muntahiyah bit tamlik. Dalam akad, dijelaskan tentang objek sewa, jangka waktu sewa, dan imbalan yang diberikan oleh lessee kepada lessor, hak opsi lessee setelah masa sewa berakhir dan ketentuan lainnya.

b) Bank syariah membeli objek sewa dari supplier. Asset yang dibeli oleh bank syariah sesuai dengan kebutuhan lessee.

c) Setelah supplier menyiapkan objek sewa, kemudian supplier mengirimkan dokumen barang yang dibeli ke bank syariah, kemudian bank syariah membayar kepada supplier.

d) Supplier mengirimkan objek sewa kepada nasabah atas perintah dari bank syariah. Barang-barang yang dikirim tidak disertai dengan dokumen karena dokumen barang diserahkan kepada bank syariah.

e) Setelah menerima objek sewa, maka nasabah mulai melaksanakan pembayaran atas imbalan yang disepakati dalam akad. Imbalan yang diterima oleh bank syariah disebut pendapatan sewa. Biaya sewa dibayar oleh nasabah kepada bank syariah pada umumnya setiap bulan. Bila jangka waktu berakhir, dan nasabah memilih opsi untuk membeli objek sewa, maka nasabah akan membayar sisanya (bila ada) dan bank syariah akan menyerahkan dokumen kepemilikan objek sewa. 


\section{Kredit Pemilikan Rumah (KPR)}

Kredit perumahan atau kredit pemilikan rumah merupakan jenis kredit perorangan kedua yang paling populer di kalangan bank umum. Seperti halnya dengan kredit kendaraan bermotor, bank dapat memberikan kredit perumahan baik secara langsung maupun tidak langsung. Pada pemberian kredit secara tidak langsung, bank memberikan kredit kepada pemborong perumahan atau perusahaan real estate, yang selanjutnya akan menyalurkan kredit tersebut kepada pembeli. Di Indonesia, kredit perumahan yang diberikan langsung kepada pembeli disebut kredit pemilikan rumah, disingkat KPR. Beberapa bank umum di Indonesia, yang pada saat buku ini disusun, memberikan kredit pemilikan rumah antara lain adalah Bank Tabungan Negara, Bank Papan Sejahtera, Bank Niaga, Bank Bali, Citibank, Bank Perkembangan Asia, Bank Umum Nasional. Bank umum di Indonesia yang memberikan kredit perumahan kepada perusahaan pemborong perumahan atau perusahaan real estate antara lain adalah bank umum pemerintah serta bank umum swasta tertentu, misalnya Bank Duta.

Ketika melayani para nasabah, bank-bank umum di Indonesia memfokuskan pemberian kredit perumahan mereka kepada golongan masyarakat tertentu. Bank Tabungan Negara misalnya, mengkhususkan diri untuk melayani anggota masyarakat golongan bawah dan menengah bawah yang ingin membeli rumah murah dengan ukuran 15-17 meter persegi, yang dibangun oleh PERUMNAS atau pemborong perumahan swasta. Kredit pemilikan rumah dari Bank Tabungan Negara diberikan dalam jangka 20 tahun dan dicicil secara bulanan. Bank Papan Sejahtera memfokuskan pemberian kredit perumahan mereka kepada masyarakat golongan menengah. Jumlah maksimum kredit yang diberikan 80\%-905\% dari nilai rumah dan tanah yang akan dibeli oleh para peminta kredit. Jangka waktu kreditnya antara 5-20 tahun dan pembayaran dilakukan dengan cara mencicil. Banyak bank-bank umum swasta melayani calon pembeli rumah dari masyarakat kelas menengah dan atas. Citibank misalnya, pada tahun 1988 dapat memberikan kredit perumahan Citibank sampai Rp. 500 juta (kurang lebih USD 225.000) untuk setiap rumah. Maksimum jangka waktu kredit perumahan Citibank adalah 7 tahun dan pembayaran kembali kredit dilakukan dengan cara mencicil, yang dilakukan tiap bulan sekali. Pada perjanjian kredit perumahan, rumah yang di biayai dengan kredit dipergunakan sebagai jaminan utama. Bagi kreditur, jaminan rumah mempunyai satu manfaat khusus, yaitu nilai jaminan kredit tersebut dari tahun ke tahun meningkat. Debitur juga sering meminta kredit perumahan untuk memperbaiki atau merenovasi rumah, dengan jaminan rumah yang akan diperbaiki tersebut. Sudah barang tentu, pada saat perbaikan rumah selesai, nilai rumah yang dipakai sebagai jaminan kredit naik. ${ }^{15}$

15 Siswanto Sutojo. Analisa Kredit Bank Umum. (Jakarta Pusat; PT Pustaka Binaman Pressindo, 1995), 37. 


\subsection{Jenis-Jenis Pembiayaan KPR}

Adapun beberapa jenis dalam pembiayaan KPR meliputi beberapa hal berikut:

1) Pembiayaan rumah baru (dari developer atau perorangan)

Pembelian rumah baru dari developer apabila dilihat dari fisik rumah dapat dibagi menjadi 2 macam, (1) Bangunan rumah sudah jadi (ready stock) dan 2) Bangunan belum jadi masih berupa tanah (indent). Apabila bangunan sudah jadi, sudah berdiri, jelas bank akan jauh lebih mudah untuk menilai fisik bangunan dan tidak sulit. Tapi bagaimana bila belum ada bangunan?, pertama developer harus mau menjalin kerja sama dengan bank terlebih dahulu (belum di-splitzing per masing-masing rumah). Hal ini sangat beresiko untuk bank maupun pembeli rumah. Untuk penilaian rumah, umumnya bank akan melihat daftar harga, beserta detail luas tanah dan bangunan. Pengikatan kredit, khusus untuk rumah yang berupa indent. Untuk meminimalkan resiko, hasil pencairan dana bisa dibagi menjadi beberapa skenario. Umumnya, pencairan dana dimasukkan ke dalam bentuk deposito atas nama developer (status blokir), deposito dapat dicairkan sesuai termin bangunan. Tetapi ini sesuai perjanjian yang dibuat sebelumnya (MOI) antara pihak developer dengan bank. Masih banyak skenario lainnya. ${ }^{16}$

2) Pembelian rumah bekas (second)

Untuk pembelian rumah bekas umumnya tidak banyak masalah. Hanya bank akan melihat dan meneliti kelengkapan dokumen dan legalitasnya. Yang pasti jaminan harus bersih tidak dalam sengketa, tidak diblokir, harus sesuai dengan buku tanah yang ada di BPN (Badan Pertahanan Nasional), dan sesuai peruntukannya dan tanahnya ada akses jalan secara fisik maupun surat (di gambar Situasi Sertifikat SHM atau SHGB), tidak ada rencana pemotongan jalan, tidak ada rencana pemerintah yang menyebabkan kerugian.

3) Pembelian ruko / rukan (sama dengan pembelian rumah bekas)

4) Pembelian apartemen baru / bekas

Untuk pembelian apartemen, sangat berbeda dengan kondisi yang lainnya. Perbedaan yang sangat menyolok adalah mengenai kepemilikan tanahnya berupa "strata title", dimana 1 petak tanah yang sama dimiliki oleh beberapa orang (karena bangunan bertingkat-tingkat). Misalnya, 1 petak 4x6 meter berdiri diatasnya 10 tingkat ke atas, maka 10 orang (dari tingkat $1 \mathrm{~s} / \mathrm{d}$ tingat 10 memiliki tanah yang sama)

Bank akan melihat lebih teliti lagi terhadap status tanahnya; SHM, SHGB atau SHGB diatas HPL. Status tanah yang ketiga inilah status yang paling beresiko, karena pada SHGB ini terdapat perjanjian tambahan di dalamnya

16 MaryantoSupriyono. Buku Pintar Perbankan. (Yogyakarta; Penerbit Andy Yogyakarta, 2011), 124. 
dengan pihak ketiga, umumnya orang awam tidak mengetahui SHGB di atas HPL. Bank juga harus mengetahui perjanjian-perjanjian lainnya dengan pihak pengelola misalnya apabila terjadi force majeur (banjir, kebakaran, gempa bumi, konstruksi retak dll), bagaimana dengan penutupan asuransi terhadap kebakaran, gempa bumi, banjir, huru-hara, dan lain-lain. SHGB di atas HPL ini tidak hanya terjadi pada apartemen, tapi bisa terjadi pada ruko, rukan, kios di mall dan lain-lain.

5) Renovasi (rumah, ruko, rukan, apartemen)

Untuk penghitungan plafon kredit KPR konstruksi butuh RAB (Rancangan Anggaran Biaya) secara detai dan gambar-gambarnya dan vendor. Pencairan dananya bisa saja per termin atau sekaligus tergantung dari situasi, kondisi, kebijakan bank dan debitur. ${ }^{17}$

\section{Implementasi}

Pada penelitian ini, peneliti melakukan wawancara kepada pihak yang menjadi informan dari bank BRI Syariah KC Malang Kawi. Adapun informan tersebut adalah sebagai berikut:

Tabel 5.1. Data Informan

\begin{tabular}{|c|c|c|l|}
\hline No & \multicolumn{1}{|c|}{ Nama } & Jabatan & \multicolumn{1}{c|}{ Jobdesk } \\
\hline 1. & Wahyu Ari Wibisono & AO & $\begin{array}{l}\text { Menarik nasabah secara } \\
\text { instansi untuk melakukan } \\
\text { pembiayaan yang akan } \\
\text { digunakan sebagai modal } \\
\text { kerja dengan berbagai } \\
\text { strategi pemasaran }\end{array}$ \\
\hline 2. & Fahmi Zakaria & $\begin{array}{l}\text { Felakukan pembukuan } \\
\text { dan penginputan seluruh } \\
\text { data atau transaksi atau } \\
\text { pembiayaan yang } \\
\text { dilakukan oleh operasional } \\
\text { perusahaan. }\end{array}$ \\
\hline 3. & Achmad Ridho & AO & $\begin{array}{l}\text { Menarik nasabah secara } \\
\text { instansi untuk melakukan } \\
\text { pembiayaan yang akan } \\
\text { digunakan sebagai modal } \\
\text { kerja dengan berbagai } \\
\text { strategi pemasaran }\end{array}$ \\
& & Legal & $\begin{array}{l}\text { Mengurusi permasalahan } \\
\text { hukum terkait pembiayaan } \\
\text { dan segala transaksi. } \\
\text { Sebagai contoh perjanjian }\end{array}$ \\
\hline 4. & $\begin{array}{l}\text { Agus Iwan } \\
\text { Sudaryanto }\end{array}$ & &
\end{tabular}

\footnotetext{
${ }^{17}$ Maryanto Supriyono, Buku Pintar Perbankan ..., 125-126.
} 


\begin{tabular}{|c|c|l|}
\hline & & $\begin{array}{l}\text { notaries, legalitas dan } \\
\text { transaksi pembiayaan serta } \\
\text { sebagai saksi akad. }\end{array}$ \\
\hline Total Informan & 4 Informan \\
\hline
\end{tabular}

\subsection{Ketentuan Akad Murabahah dan IMBT}

Menurut Fahmi Zakaria transaksi kredit pemilikan rumah (KPR) pada bank BRI Syariah didasarkan pada ketentuan pihak DPS bank BRI Syariah yang merujuk pada ketentuan DSN-MUI. Mekanisme yang dilakukan menggunakan akad murabahah dan IMBT yang sesuai dengan fatwa DSN MUI No. 04/DSN-MUI/IV/2000 tentang murabahah dan fatwa DSN MUI No. 27/DSN-MUI/III/2002 tentang ijarah muntahiyah bit tamlik. Akad murabahah dan ijarah muntahiyah bit tamlik (IMBT) merupakan akad yang digunakan pada produk KPR di bank BRI Syariah KC Malang Kawi. Pada produk KPR di bank BRI Syariah, selain menggunakan akad murabahah dan ijaraha muntahiyah bit tamlik juga disertai dengan akad wakalah karena pihak bank tidak memiliki atau tidak menyediakan barang yang di minta nasabah, sehingga membutuhkan barang dari pihak lain dan bank sebagai wakil yang menyediakan barang tersebut. ${ }^{18}$

\subsection{Jenis Transaksi KPR}

\section{1) KPR Faedah}

Menurut Wahyu Ari Wibisono,jenis transaksi KPR yang digunakan pada Bank BRI Syariah KC Malang Kawi adalah produk KPR Faedah BRI Syariah. Produk KPR Faedah ini menggunakan akad murabahah dimana pihak Bank akan membelikan atau rumah yang sesuai dengan pesanan atau yang diminta oleh nasabah. Pada awalnya nasabah yang mengajukan pembiayaan rumah akan dilihat dari jumlah pendapatan yang diterima untuk mengetahui berapa jumlah biaya yang dapat dikeluarkan oleh bank. Selanjutnya melakukan BI checking untuk melihat apakah nasabah tersebut memiliki pinjaman di bank lain. Setelah melakukan BI checking, dilakukanlah appraisal atau penilaian terhadap jaminan apakah layak atau tidak guna diberikan kepada pihak Bank sebagai jaminan pembiayaan KPR. Apabila jaminan tersebut sudah disetujui dan diterima oleh pihak bank, maka kemudian tidak langsung begitu saja memberikan nominal pembiyaan, melainkan hanya memberikan $80 \%$ (ketentuan dari pusat) dari nilai jaminan tersebut. ${ }^{19}$ Pada dasarnya yang menjadi patokan dalam pemberian pembiayaan rumah disini adalah dilihat dari jumlah pendapatan

18 Hasil wawancara dengan Fahmi Zakaria (Financing Administration), Malang, 4 Oktober 2017, pukul 13.40 WIB. WIB.

19 Wawancara dengan Wahyu Ari Wibisono (AO), Malang, 12 Oktober 2017, pukul 14.30 
nasabah tersebut. Pada produk KPR Faedah, angsuran pokok semakin lama akan semakin banyak dan angsurn margin semakin lama akan semakin sedikit, namun pada pembayaran angsuran perbulan akan tetap sampai akhir periode pelunasan. Adapun estimasi angsuran KPR Faedah BRI Syariah adalah sebagai berikut: ${ }^{20}$

Tabel 5.2: Angsuran KPR Faedah

\begin{tabular}{|c|r|r|r|}
\hline $\begin{array}{c}\text { KPR } \\
\text { Murabahah }\end{array}$ & \multicolumn{3}{|c|}{ Jangka Waktu (bulan) } \\
\hline PLAFON & $\mathbf{6 0}$ & $\mathbf{1 2 0}$ & $\mathbf{1 8 0}$ \\
\hline $100,000,000$ & $2,249,794$ & $1,493,107$ & $1,314,987$ \\
\hline $250,000,000$ & $5,624,485$ & $3,732,768$ & $3,287,468$ \\
\hline $500,000,000$ & $11,248,969$ & $7,465,537$ & $6,574,936$ \\
\hline $750,000,000$ & $16,873,454$ & $11,198,305$ & $9,862,405$ \\
\hline $1,000,000,000$ & $22,497,938$ & $14,931,074$ & $13,149,873$ \\
\hline - Angsuran pembiayaan tetap hingga fasilitas pembiayaan lunas \\
\hline - Bebas biaya administrasi dan profisi
\end{tabular}

\section{2) IMBT KPR}

Menurut Agus Iwan Sudaryanto jenis transaksi lainnya selain produk KPR Faedah BRI Syariah adalah IMBT KPR. Produk ini tidak jauh berbeda dengan produk KPR faedah, baik dari segi persyaratan maupun alur pemberian pembiayaan. Yang membedakan terletak pada angsuran pokok. Pada produk KPR Faedah yang menggunakan akad murabahah, jumlah angsuran pokok dari awal periode cicilan sampai akhir periode pelunasan memiliki jumlah yang tidak tetap. Pada awal periode pembayaran cicilan, nominal angsuran pokok berjumlah kecil dan akan semakin banyak sampai akhir pelunasan. Sedangkan pada angsuran margin, awal cicilan akan berjumlah sedikit dan nominal setiap bulannya akan bertambah sampai akhir pelunasan. Namun pada IMBT KPR, jumlah angsuran pokok dari awal pembayaran sampai akhir pelunasan memiliki jumlah yang tetap, sedangkan angsuran ujrahnya akan besar di awal dan semakin lama akan semakin sedikit sampai pada akhir pelunasan. ${ }^{21}$

\subsection{Perhitungan Margin dan Angsuran}

Setiap perusahaan pasti bertujuan untuk memperoleh keuntungan (profit) baik itu lembaga keuangan maupun lembaga non kuangan, Bank BRI Syariah KC

\footnotetext{
${ }^{20}$ Dokumentasi, Brosur KPR Faedah pada Bank BRI Syariah KC Malang Kawi

${ }^{21}$ Wawancara dengan Agus Iwan Sudaryanto(Legal), Malang, 9 Oktober 2017, pukul 16.00 WIB.
} 
Malang Kawi pun demikian. Perolehan margin didapat dari kesepakatan antara nasabah dan pihak bank. Menurut Achmad Ridho sistem yang dipakai dapat disebut seperti piramida terbalik. Pada periode awal margin yang dikenakan akan berjumlah lebih besar dari biaya pokok, semakin lama margin tersebut akan semakin berkurang. Sebaliknya, biaya pokok pada periode pembayaran awal akan berjumlah lebih sedikit dari pada biaya margin, semakin lama maka jumlah biaya pokok akan semakin besar sampai batas akhir periode pelunasan pinjaman nasabah (Murabahah).Pada KPR IMBT, angsuran pokok memiliki nilai yang tetap dari awal pembayaran sampai akhir pelunasan dengan angsuran ujrah yang besar diawal dan semakin lama akan semakin menurun. ${ }^{22}$

\section{Tabel 5.3: Sistem Angsuran dan Margin}

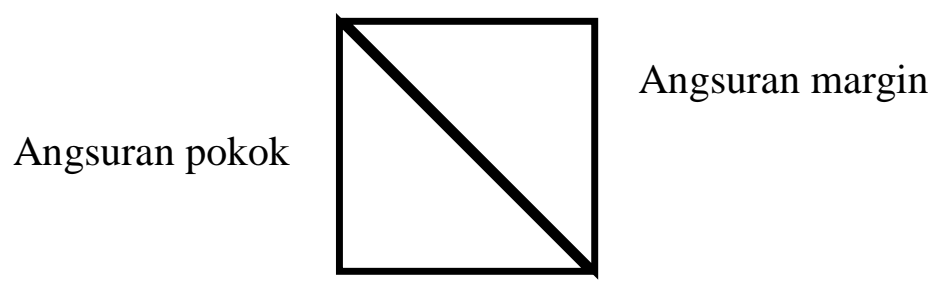

Ketentuan margin yang digunakan tergantung pada ketentuan Bank. Untuk saat ini margin yang digunakan adalah :

$$
\begin{array}{ll}
-\quad 1-5 \text { tahun } & : 12,5 \% \\
-\quad 6-10 \text { tahun } & : 13 \% \\
-\quad 11-15 \text { tahun } & : 13,75 \%
\end{array}
$$

\subsection{Alur Transaksi KPR Di BRI Syariah KC Malang Kawi}

Pada pengajuan kredit pembiayaan rumah (KPR) di bank BRI Syariah KC Malang kawi, ada beberapa alur yang harus dilakukan oleh pihak marketing kepada nasabah sebelum surat persetujuan pembiayaan. Adapun alur yang dilakukan adalah sebagai berikut: ${ }^{23}$

\footnotetext{
${ }^{22}$ Wawancara dengan Achmad Ridho (AO), Malang, 3 Oktober 2017, pukul 10.30 WIB.

23 Wawancara dengan Wahyu Ari Wibisono (AO). Malang, 12 Oktober 2017 pukul 14.30 WIB.
} 


\section{Gambar 5.4: Alur Transaksi KPR}

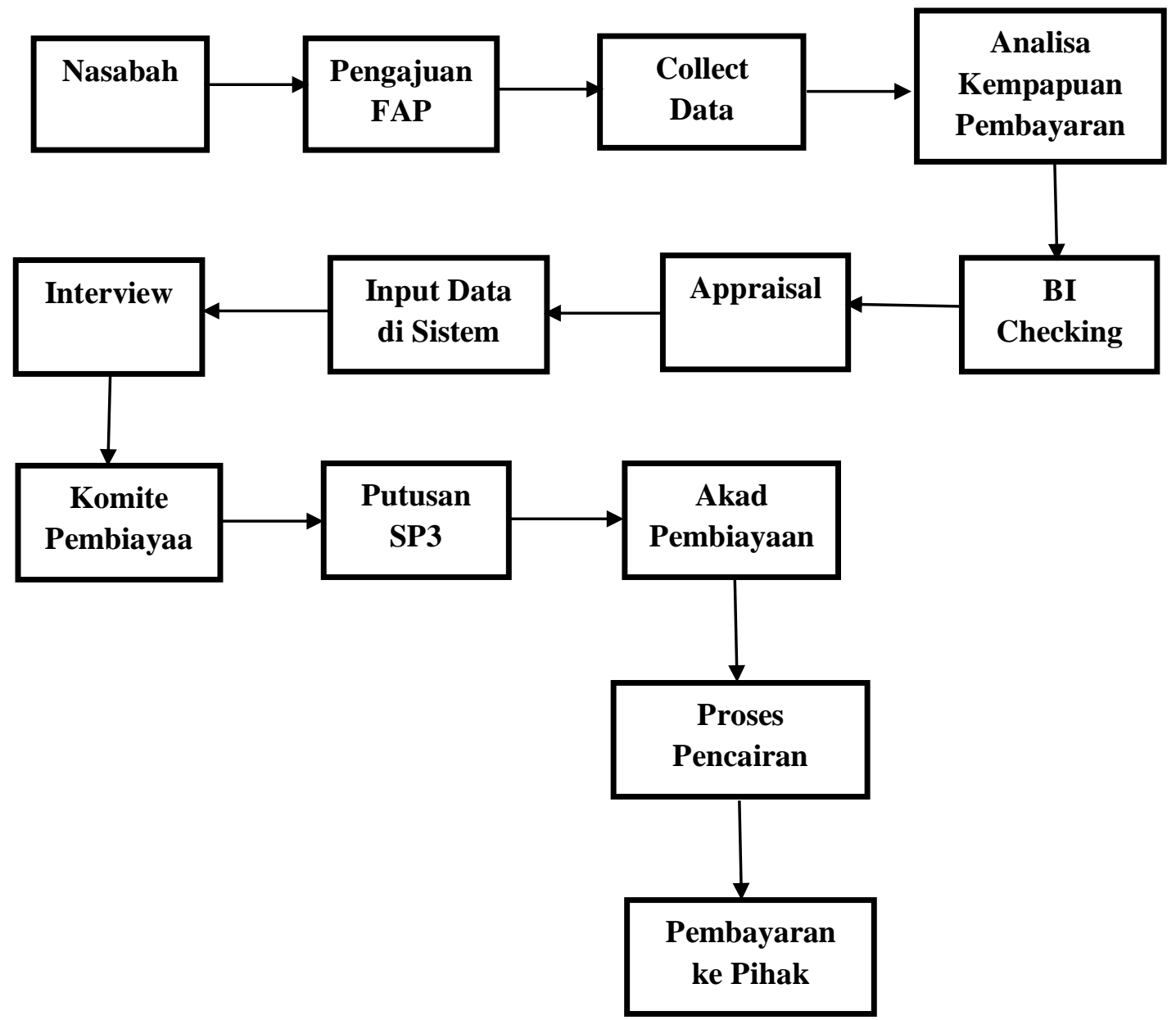

Keterangan:

1) Nasabah yang ingin melakukan pengajuan pembiayaan rumah datang ke bank.

2) Kemudian nasabah mengisi FAP (Form Aplikasi Permohonan) yang disediakan oleh bank guna mengetahui data-data dan informasi pendukung seputar nasabah.

3) Kemudian pihak bank mengumpulkan data utama calon nasabah.

4) Setelah itu AO menganalisa kemampuan nasabah membayar pembiayaan rumah tersebut.

5) Kemudian pihak bank atau AO melakukan BI Checking yang berfungsi untuk pemeriksaan riwayat kredit nasabah dengan mengacu pada data BI (Bank Indonesia).

6) Setelah itu appraisal atau penilaian jaminan untuk melihat layak atau tidaknya nasabah tersebut untuk dibiayai.Apabila jaminan tersebut sudah disetujui dan diterima oleh pihak bank, maka kemudian tidak langsung 
begitu saja memberikan nominal pembiyaan, melainkan hanya memberikan $80 \%$ (ketentuan dari pusat) dari nilai jaminan tersebut.

7) Kemudian seluruh data yang di dapat di input pada sistem BRIS.

8) Kemudian dilakukanlah interview dengan nasabah (cross check data dan pendapatan)

9) Setelah itu pengajuan kepada komite pembiayaan apakah disetujui atau tidak.

10) Setelah itu diterbitkanlah SP3 (Surat Persetujuan Prinsip Pembiayaan).

11) Kemudian dilakukanlah akad pembiayaan.

12) Kemudian dilakukan proses pencairan dana.

13) Yang terakhir adalah proses pembayaran ke pihak penjual.

\subsection{Analisis Keseuaian Antara Teori dan Praktik}

Berdasarkan penelitian yang telah dilakukan pada bank BRI Syariah KC Malang Kawi, di dapatkan beberapa persamaan dan perbedaan dari informasi yang didapat dari teori dan praktik. Adapun perbedaan dan persamaan tersebut akan dijelaskan pada tabel berikut:

Tabel 5.5: Analisis Kesesuaian Teori dan Praktik

\begin{tabular}{|c|c|c|c|}
\hline No & Uraian & $\begin{array}{r}\text { Teori } \\
\end{array}$ & Praktek \\
\hline 1. & $\begin{array}{l}\text { Ketetapan hukum } \\
\text { murabahah dan } \\
\text { IMBT }\end{array}$ & $\begin{array}{l}\text { Akad Murabahah dan } \\
\text { IMBT berlandaskan hukum } \\
\text { yang berasal dari Al- } \\
\text { Qur'an, Hadits, serta ijma' } \\
\text { para ulama. }\end{array}$ & $\begin{array}{l}\text { Transaksi kredit pemilikan } \\
\text { rumah (KPR) pada bank } \\
\text { BRI Syariah didasarkan } \\
\text { pada ketentuan pihak DPS } \\
\text { bank BRI Syariah yang } \\
\text { merujuk pada ketentuan } \\
\text { DSN-MUI. Sesuai dengan } \\
\text { fatwa DSN MUI No. } \\
\text { 04/DSN-MUI/IV/2000 } \\
\text { tentang murabahah dan } \\
\text { fatwa DSN MUI No. } \\
\text { 27/DSN-MUI/III/2002 } \\
\text { tentang ijarah muntahiyah } \\
\text { bit tamlik. }\end{array}$ \\
\hline 2. & $\begin{array}{l}\text { Mekanisme akad } \\
\text { murabahah dan } \\
\text { IMBT di Bank } \\
\text { Syariah }\end{array}$ & $\begin{array}{l}\text { Mekanisme } \\
\text { murabahah : } \\
\text { 1. } \\
\text { Bank syariah } \\
\text { dan nasabah melakukan } \\
\text { negosiasi. } \\
\text { 2. Bank syariah } \\
\text { melakukan akad jual } \\
\text { beli dengan nasabah, }\end{array}$ & $\begin{array}{l}\text { Mekanisme produk KPR } \\
\text { di BRI Syariah KC } \\
\text { Malang Kawi : } \\
\text { 1. Nasabah yang } \\
\text { ingin melakukan } \\
\text { pengajuan pembiayaan } \\
\text { rumah datang ke bank. } \\
\text { 2. Kemudian nasabah }\end{array}$ \\
\hline
\end{tabular}




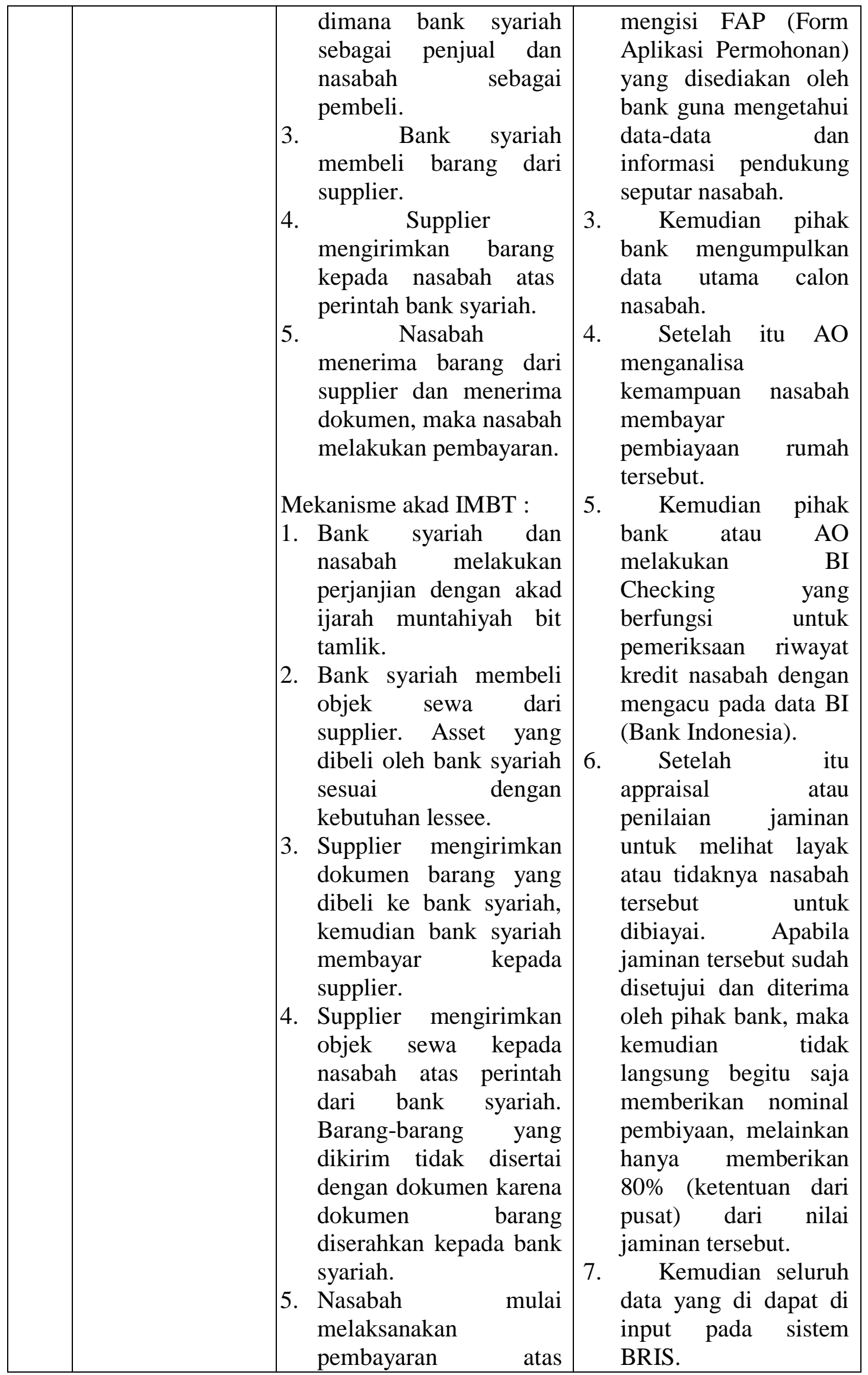




\begin{tabular}{|c|c|c|c|}
\hline & & $\begin{array}{l}\text { imbalan yang disepakati } \\
\text { dalam akad. } \\
\text { kepemilikan } \\
\text { sewa. }\end{array}$ & 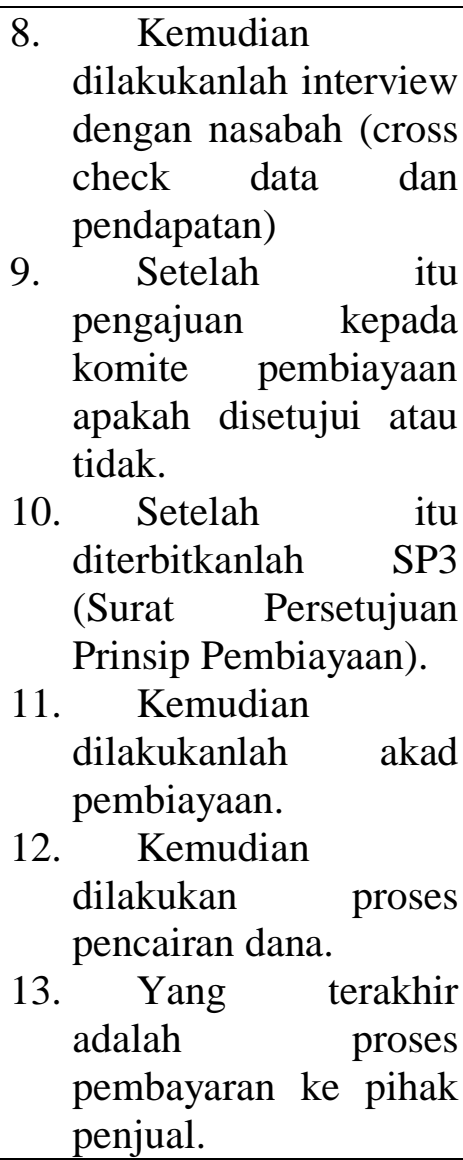 \\
\hline 3. & Angsuran & $\begin{array}{l}- \text { Angsuran (pokok }+ \\
\text { bunga) tetap : Anuitas } \\
\text { - Pokok tetap - bunga } \\
\text { menurun : Efektif }\end{array}$ & $\begin{array}{l}\text { Sistem yang dipakai dapat } \\
\text { disebut seperti piramida } \\
\text { terbalik. Dimana pada } \\
\text { periode awal margin yang } \\
\text { dikenakan akan berjumlah } \\
\text { lebih besar dari biaya } \\
\text { pokok, semakin lama } \\
\text { margin tersebut akan } \\
\text { semakin berkurang. } \\
\text { Sebaliknya, biaya pokok } \\
\text { pada periode pembayaran } \\
\text { awal akan berjumlah lebih } \\
\text { sedikit dari pada biaya } \\
\text { margin, semakin lama } \\
\text { maka jumlah biaya pokok } \\
\text { akan semakin besar } \\
\text { sampai batas akhir periode } \\
\text { pelunasan pinjaman } \\
\text { nasabah (murabahah). } \\
\text { Sedangkan pada KPR } \\
\text { IMBT, angsuran pokok } \\
\text { memiliki nilai yang tetap } \\
\text { dari awal pembayaran } \\
\text { sampai akhir pelunasan }\end{array}$ \\
\hline
\end{tabular}




\begin{tabular}{|l|l|l|}
\hline & $\begin{array}{l}\text { dengan angsuran ujrah } \\
\text { yang besar diawal dan } \\
\text { semakin lama akan } \\
\text { semakin menurun. }\end{array}$ \\
\hline
\end{tabular}

\section{Kesimpulan}

Berdasarkan pembahasan di atas, dapat disimpulkan beberapa hal berikut: analisis antara teori dan praktik yang ada, dapat diseimpulkan beberapa hal berikut: (1) Ketetapan hukum antara teori dan praktek akad murabahah dan IMBT telah sesuai karena pada Fatwa DSN MUI yang menjadi landasannya pun adalah Al-Qur'an, hadits dan ijma' ulama. (2) Mekanisme akad murabahah dan IMBT yang diterapkan pada produk KPR bank BRI Syariah telah sesuai dengan ketentuan syariah, (3) Pada angsuran, bank BRI Syariah menggunakan sistem piramida terbalik atau efektif, dimana angsuran pokok tetap dan marginnya semakin lama semakin menurun sampai akhir pelunasan pembiayaan.

Produk KPR pada bank BRI Syariah KC Malang Kawi menggunakan akad murabahah dan ijarah muntahiyah bit tamlik (IMBT) yang sesuai dengan fatwa DSN MUI No. 04/DSN-MUI/IV/2000 tentang murabahah dan fatwa DSN MUI No. 27/DSN-MUI/III/2002 tentang ijarah muntahiyah bit tamlik (IMBT). Pada produk KPR Faedah yang menggunakan akad Murabahah, sistem yang digunakan adalah jual beli dimana barang akan dikirim kepada nasabah saat pihak bank telah melakukan pembelian pada agen. Selanjutnya nasabah akan mulai menyicil pembayaran sampai akhir pelunasan. KPR IMBT yang menggunakan sistem Ijarah Muntahiyah Bit Tamlik memiliki opsi pilihan yang membedakannya dengan KPR Faedah. Pada akhir pelunasan, KPR IMBT memberikan opsi untuk kepemilikan atau tidak kepada nasabah. Sisa pokok pada KPR IMBT memiliki jumlah yang lebih sedikit dari pada KPR Faedah yang menggunakan akad murabahah.

Mekanisme transaksi Kredit Pemilikan Rumah (KPR) di Bank BRI Syariah KC Malang Kawi melalui beberapa tahap berikut: pertama, nasabah yang ingin melakukan pengajuan pembiayaan rumah datang ke bank. Kedua, nasabah mengisi FAP (Form Aplikasi Permohonan) yang disediakan oleh bank guna mengetahui data-data dan informasi pendukung seputar nasabah. Ketiga, pihak bank mengumpulkan data utama calon nasabah. Keempat, selanjutnya AO menganalisa kemampuan nasabah membayar pembiayaan rumah tersebut. Kelima, pihak bank atau AO melakukan BI Checking yang berfungsi untuk pemeriksaan riwayat kredit nasabah dengan mengacu pada data BI (Bank Indonesia). Keenam, selanjutnya adalah penilaian jaminan (appraisal) untuk melihat layak atau tidaknya nasabah tersebut untuk dibiayai. Apabila jaminan tersebut sudah disetujui dan diterima oleh pihak bank, maka kemudian tidak langsung begitu saja memberikan nominal pembiyaan, melainkan hanya memberikan $80 \%$ (ketentuan dari pusat) dari nilai jaminan tersebut. Ketujuh, seluruh data yang di dapat di input 
pada sistem BRIS. Delapan, dilakukan proses interview dengan nasabah (cross check data dan pendapatan). Sembilan, pengajuan kepada komite pembiayaan apakah disetujui atau tidak. Sepuluh, penerbitan SP3 (Surat Persetujuan Prinsip Pembiayaan). Sebelas, realisasi akad pembiayaan. Duabelas, proses pencairan dana dan proses pembayaran ke pihak penjual.

\section{Daftar Pustaka}

Haris, H. 2007. Pembiayaan Kepemilikan Rumah (sebuah inovasi pembiayaan perbankan syariah). La Riba: Jurnal Ekonomi Islam, 1(1), 113-125

Hasan, M Ali. 2004. Berbagai Macam Transaksi Dalam Islam. Jakarta: PT RajaGrafindo Persada

Ismail. 2011. Perbankan Syariah. Jakarta: Kencana Prenadamedia Group

Latifa M, Algaud, \& Mervy K. Lewis. 2003. Perbankan Syariah Prinsip, Dan Prospek. Jakarta: PT Serambi Ilmu Semesta

Muhammad. 1987. Manajemen Bank Syariah. Yogyakarta: UPP AMP YKPN

Mujahidin, Akhmad. 2016. Hukum Perbankan Syariah. Jakarta; PT Rajagrafindo Persada

Salman, Kautsar Riza. 2012. Akuntansi Perbankan Syariah Berbasis PSAK Syariah. Jakarta: Akademia Permata.

Syafe'I, Rachmat. 2001. Fiqih Muamalah. Bandung; CV. Pustaka Setia

Supriyono, Maryanto. 2011. Buku Pintar Perbankan. Yogyakarta; CV. ANDI OFFSET

Sutojo, Siswanto. 1995. Analisis Kredit Bank Umum. Jakarta; Pustaka Binaman Pressindo

Somantri, Gumilar Rusliwa. "Memahami metode kualitatif." Makara Hubs-Asia 8.3 (2010). 